\title{
Responses of inflammation signaling pathway by saucerneol $D$ from elicitor-treated Saururus chinensis on pro-inflammatory responses in LPS-stimulated Raw 264.7 cell
}

\author{
Eun-Ho Lee and Young-Je Cho* (1)
}

\begin{abstract}
This study confirmed the association with inflammation-related proteins, mediators, and cytokines using saucerneol D from Saururus chinensis leaf, a useful ingredient increased through elicitor treatment. To confirm the anti-inflammatory effect, saucerneol D were treated with lipopolysaccharide, which induces pro-inflammatory factors in Raw 264.7 cell. The pro-inflammatory influences were measured by dint of chemical assay and western blotting as well as ELISA. As a result, the content of saucerneol D was changed when eicitor was treated by various concentration $(1.5$, and $3 \mathrm{mg}$ / $\mathrm{mL}$ ) in S. chinensis leaves. In addition, the expression levels of hyaluronidase and pro-inflammatory-related factors [nitric oxide (NO), inducible NO synthase (iNOS), and cyclooxygenase-2 (COX-2)] were regulated according to the saucerneol $D$ content in the elicitor-treated and non-treated groups. Therefore, after confirming that saucerneol $D$ has an inhibitory effect on pro-inflammatory-related factors, saucerneol D was adjusted by concentration and compared with the control substance to verify the efficacy. Saucerneol D was adjusted to a concentration that did not toxic to macrophages through 3-(4,5-dimethylthiazol-2-yl)-2,5-diphenyltetrazolium bromide (MTT) assay. Saucerneol D controlled at various concentrations inhibited iNOS and COX-2 proteins. NO produced by iNOS activity, prostaglandin $\mathrm{E}_{2}$ $\left(\mathrm{PGE}_{2}\right)$, an inflammatory mediator produced by COX-2 activity, and pro-inflammatory cytokines [interleukin-1 $\beta$ (IL-1 $\left.\beta\right)$, IL-6, tumor necrosis factor-a (TNF-a)] were significantly suppressed. Therefore, it was confirmed that saucerneol $D$, an active ingredient increased by the elicitor treatment, could be used as a functional material that controls inflammatory factors.
\end{abstract}

Keywords: Cytokine, Elicitation, Inflammation, Macrophages, Saucerneol D

\section{Introduction}

Studies have reported several natural substances that are necessary or important to cultivate healthy lifestyles substances of plant origin have been the subject of much research in this regard. And the wild plants produce substances can prevent or cure diseases [1-3]. Elicitor technology is a technology that induces plants

*Correspondence: yjcho@knu.ac.kr

School of Food Science \& Biotechnology/Food \& Bio-Industry Research

Institute, Kyungpook National University, 80 University Street, Bukgu, Daegu 41566, Republic of Korea to artificially produce more phytoalexin by processing Elicitor. Plants themselves produce potentially useful substances in the plant body as a way to defend against attacks by external stimuli, such as worms and pathogens. When applied, this technology is applied to a plant, the plant's defense system recognizes the processed elicitor as an attack from foreign pathogens. So, in order to protect itself, it artificially induces excessive production of useful substances by using the principle of producing phytoalexin, an antitoxic substance produced by plant tissues. The method of treating the inducing agent has an advantage of treating the 
inducing agent immediately before harvesting when cultivating the plant, and having a high content of useful components and ensuring high-quality materials. In addition, according to a study by Lee and Cho [4], the change of total phenolics content (TPC), difference in HPLC profile, and the modulating effect of biological enzyme were different reported according to the concentration of elicitor treated in the extract of Oplismenus undulatifolius treated with elicitor.

Saururus chinensis Baill. is a perennial plant classified in the Sauceraceae family and is utilized as an oriental medicine when dried $[5,6]$ its pharmacological effects aid the alleviation of fever, anti-inflammation, dropsy, beriberi, hepatitis, jaundice, cancer and other ailments [5]. The major components of S. chinensis are hyperion, rutin, queroetin, quercetin, quercertrin, and other flavonoids $[7,8]$. Flavonoids are mainly used as natural antioxidants because the results of research on antioxidants are well known, and because they have a preventive effect against oxidative stress [9]. They also play a key role in preventing or slowing down aging, cancer, and heart disease. Flavonoids have several uses, including as food and in the pharmaceutical and cosmetics industries. Nowadays, among the studies that have been done on various natural compounds, a particular interest has been focused on the flavonoids as being the main compound with anti-oxidative properties $[10,11]$.

Macrophages are activated by low concentrations of lipopolysaccharide (LPS), also known as lipoglycans and endotoxins, and produce and release inflammatory mediator, toll like receptor, reactive oxygen intermediate, nitric oxide (NO) and other compounds $[12,13]$. Macrophages may also secrete phosphatase, chemokine, and cytokines, for instance tumor necrosis factor- $\alpha$ (TNF- $\alpha)$, interferon, interleukin- $1 \beta$ (IL-1 $\beta)$, IL-6, hyaluronan synthase 2, monocyte chemoattractant protein-1 (MCP-1), and transforming growth factor- $\beta$ (TGF- $\beta$ ), when activated, as a defense mechanism which involves inflammatory activity, hematopoietic organs, and others as part of the body's immune system [14-16].

In the present study, we sought to identify, purify, and test the inflammation inhibitory properties of flavonoid compounds extracted from elicitor-treated S. chinensis. Anti-inflammatory properties were assessed employing macrophages, and the western blot method was utilized to observe changes in protein content. Also, in this study, the elicitation technique was applied to $S$. chinensis to improve the efficacy research content using existing pharmacological plants, and the anti-inflammatory effect of saucerneol D, a useful ingredient produced from S. chinensis, was investigated.

\section{Materials and methods}

Production and application of elicitor on S. chinensis

The main component of the elicitor used in the study is a polysaccharide carbohydrate, a polysaccharide derived from the cell wall of microorganisms acting as a pathogen for plants. The purified yeast $\left(210929\right.$, Difco $^{\mathrm{TM}}$, Sparks, MD, USA) enzyme digestion product after protease treatment is the separation of polysaccharide from yeast autolysate. In the yeast enzyme digestion product, a proteolytic enzyme was applied to the yeast extract aqueous solution, and then an excess of ethanol was added to induce ethanol-insoluble components. Then, the precipitate was recovered and dried to prepare a powder state. Protease is an enzyme that hydrolyzes protein-peptide bonds, and a protease isolated from Aspergillus fumigatus [17] was used. $1 \mathrm{~kg}$ of yeast extract powder prepared according to the above method was homogenized with $5 \mathrm{~g}$ of copper chloride $\left(\mathrm{CuCl}_{2}\right)$ to produce the elicitor powder [18].

The elicitor processing technique is a technique that artificially induces useful components generated inside a plant. High-quality materials with high content can be produced through one time or more treatments of inducing agents in a short period just before harvest. S. chinensis, the target of elicitor treatment, is a perennial plant, but for the purpose of experimentation, it was cultivated for 1 year and harvested by treating elicitor. The concentration for preparing the elicitor solution was set based on 1.5 , and $3 \mathrm{mg} / \mathrm{mL}$, and the distribution degree of the $4 \mathrm{~m}^{2}$ area was measured for each growth stage, dissolved in $1 \mathrm{~L}$, and treated three times. The first application was carried out when the $S$. chinensis leaves had grown to approximately one-fourth their full size (April 30th, $0.375 \mathrm{~g} / \mathrm{L}$ and $0.75 \mathrm{~g} / \mathrm{L}$ ). The elicitor was sprayed directly on the bottom part of the leaves on a $4 \mathrm{~m}^{2}$ area in both groups A and B. A similar second application was carried out at $50 \%$ leaf growth (May 7 th, $0.75 \mathrm{~g} / \mathrm{L}$ and $1.5 \mathrm{~g} / \mathrm{L}$ ). The final application was carried out at $75 \%$ leaf growth (May 14th, $1.125 \mathrm{~g} / \mathrm{L}$ and $2.25 \mathrm{~g} / \mathrm{L}$ ) $[4,18]$.

\section{Preparatory stage of extracts from elicitor-treated $S$. chinensis}

For the samples of the elicitor-treated and the nontreated group, only the leaves of the above-ground part of the $S$. chinensis were collected, foreign substances were removed, and naturally dried, and then ground to 40 mesh was used. Then, preparation of extract experimental samples was $1 \mathrm{~g}$ of $S$. chinensis leaves powder was mixed with $100 \mathrm{~mL}$ of $70 \%$ ethanol, homogenized for $1 \mathrm{~min}$ at $16,000 \mathrm{rpm}$, and agitated for $24 \mathrm{~h}$. Finally, the sample extracts was filtered and concentrated by utilizing a filter paper No. 41 (Whatman Inc., Piscataway, NJ, USA) and Buchi rotavapor (Buchi Labortechnik AG, 
Flawil, Switzerland). The extracted extract was freezedried (freeze dryer, FD8518, Ilshinbiobase, Yangju, Korea) to remove moisture, and then stored at a low temperature in a sample storage refrigerator at $4{ }^{\circ} \mathrm{C}$ or $-20^{\circ} \mathrm{C}$ and used for experiments.

\section{Determination of hyaluronidase (HAase) inhibition}

In the HAase inhibition experiment, as the extract sample is treated, the substrates sodium hyaluronic acid (HA) and $\rho$-dimethylaminobenzaldehyde react and affect the activity of HAase to change the color of the reactant. Briefly, $0.05 \mathrm{~mL}$ HAase solution $(7900 \mathrm{U} / \mathrm{mL})$ dissolved in $0.1 \mathrm{M}$ acetate buffer $(\mathrm{pH} 3.5)$ and $0.1 \mathrm{~mL}$ of extracts from S. chinensis were mixed and incubated for $20 \mathrm{~min}$ at $37{ }^{\circ} \mathrm{C}$. Then, $12.5 \mathrm{mM}$ calcium chloride $\left(\mathrm{CaCl}_{2}\right)(0.1 \mathrm{~mL})$ was added and HA $(12 \mathrm{mg} / \mathrm{mL})$ dissolved in $0.1 \mathrm{M}$ acetate buffer ( $\mathrm{pH}$ 3.5) was added as substrate. Next, $0.1 \mathrm{~mL}$ of $0.4 \mathrm{~N}$ potassium tetraborate $\left(\mathrm{K}_{2} \mathrm{~B}_{4} \mathrm{O}_{7}\right)$ and $0.1 \mathrm{~mL}$ of $0.4 \mathrm{~N}$ sodium hydroxide $(\mathrm{NaOH})$ solution was added to the reacted mixture, boiled in a water bath. Then, $3 \mathrm{~mL}$ $\rho$-dimethylaminobenzaldehyde, which is a color forming reagent, was added to the cooled mixture and incubated for 20 min at $37^{\circ} \mathrm{C}$. Absorbance (Optizen 3220 UV, Merasys Co. Ltd.) was measured at $585 \mathrm{~nm}$ and the inhibitory activity was calculated as previously reported [19].

\section{Purification and chemical structure assay}

The material was purified using MCI gel CHP-20 column and Sephadex LH-20. The purified active single compound was a colorless powder and melting point was $75-76{ }^{\circ} \mathrm{C}$. The angle of rotation $\left[[\alpha]_{D}^{25}\right]$ was $-88.1^{\circ}$. Molecular weight at positive FAB-MS was 554, with active groups of 3490,2960, 2920, 2900, 1605, and 1595 in $\mathrm{KBr}$ IR spectrum $\left(\mathrm{cm}^{-1}, \mathrm{KBr}\right)$ were identified. ${ }^{1} \mathrm{H}$ - and ${ }^{13} \mathrm{C}$-NMR data were consistent with the literature values [20].

\section{Determination of TPC and saucerneol D content}

The TPC was measured by referring to the method tested by Folin-Denis [21]. The TPC was measured at $725 \mathrm{~nm}$ using an absorbance instrument (Optizen 3220 UV, Merasys Co. Ltd., Seoul, Korea). For the measurement, $1 \mathrm{~N}$ Folin-Ciocalteu reagent was used for color development, and the result was measured within $1 \mathrm{~h}$. Quantification of the TPC was calculated using a gallic acid standard curve, and the content of saucerneol D was analyzed by HPLC and measured by applying purified saucerneol D to the standard curve.

\section{Cell culture}

Raw 264.7 cell were cultured for $24 \mathrm{~h}$ at $5 \% \mathrm{CO}_{2}$ and $37^{\circ} \mathrm{C}$ in a mixed medium composed of $10 \%$ fetal bovine serum (FBS), 1\% streptomycin, and 1\% penicillin in Dulbecco's modified Eagle's medium (DMEM). Cells were subcultured in $100 \times 20 \mathrm{~mm}$ culture dishes at a density $2-3 \times 10^{6}$ cells $/ \mathrm{mL}$ to maintain growth conditions. Cells were passaged at $80 \%$ confluency and the passage number was maintained at under 20 during the experiment $[7,22]$.

\section{Analysis of cell viability by 3-(4,5-dimethylthiazol-2-yl)-2,5-diphenyltetrazolium bromide (MTT) assay}

Toxicity to macrophages was definite by reference to the method described by Carmichael at el. [23]. Aliquots of $0.18 \mathrm{~mL}$ of macrophages were utilized in 96-well plates at a density of $5 \times 10^{4}$ cells $/ \mathrm{mL}$. Samples $(2 \mathrm{~mL})$ of various concentrations $(6.25-50 \mu \mathrm{g} / \mathrm{mL})$ was treated and incubated for $18 \mathrm{~h}$ at $37^{\circ} \mathrm{C}$ employing $5 \% \mathrm{CO}_{2}$ incubator (311, Thermo Fisher Scientific, Waltham, MA, USA). Subdivision of $0.02 \mathrm{~mL}$ of a concentrated MTT solution $(3 \mathrm{mg} /$ $\mathrm{mL}$ ) was added and after incubated for $3 \mathrm{~h}$, medium was subduct and, $0.3 \mathrm{~mL}$ of DMSO was added to each well, and the reaction was permitted to proceed for $30 \mathrm{~min}$ at ordinary temperature. The OD at $540 \mathrm{~nm}$ was recorded (SPECTROstar Nano, BGM Labtech, Ortenberg, Germany) by applying an ELISA reader. The determination of toxicity to the cells was made via measurement of the OD of the sample and control groups in the calculation: cell viability rate $(\%)=($ sample group $/$ normal group $) \times 100$. The control group was incubated in the same conditions excepted they were treated with equal amounts of DW instead of MTT.

\section{Determination of NO production}

Cells were cultured in 96-well plates at a density of $1 \times 10^{5}$ cells $/ \mathrm{mL}$ by incubation for over $12 \mathrm{~h}$, at $37^{\circ} \mathrm{C}$. Then, LPS $(1 \mu \mathrm{g} / \mathrm{mL})$ was used to stimulate cells in all wells except for the normal group. Then $6.25-50 \mu \mathrm{g} / \mathrm{mL}$ of saucerneol D was added and the cells incubated for $18 \mathrm{~h}[7,14,24]$. The supernatant of the cells medium and cells was used for measuring the concentration of NO by the Griess reagent system's kit (Promega, Madison, Wisconsin, USA) according to the manufacturer's protocol.

\section{Western blot analysis}

Measurements of iNOS and COX-2 protein expression levels were conducted using Raw 264.7 cell seeded in 6 -well tissue culture plates at $5 \times 10^{5}$ cells $/ \mathrm{mL}$. After incubating for $24 \mathrm{~h}$ in a $\mathrm{CO}_{2}$ incubator at $37{ }^{\circ} \mathrm{C}, 1 \mu \mathrm{g} /$ $\mathrm{mL}$ LPS and/or indicated concentrations of saucerneol $\mathrm{D}(25 \mu \mathrm{g} / \mathrm{mL})$ were added, and the plates were incubated for $18 \mathrm{~h}$ and washed with PBS. Seventy microliters of a mixture of M-PER Mammalian Protein Extraction Reagent (Thermo Fisher Scientific.) with $1 \times$ protease inhibitor (Thermo Fisher Scientific.) was added to each well 
and cells were lysed at $4{ }^{\circ} \mathrm{C}$, followed by centrifugation at $16,000 \mathrm{rpm}$ for $20 \mathrm{~min}$ at $4{ }^{\circ} \mathrm{C}$ (Gyrozen, Seoul, Korea) to remove insoluble debris. After separation, protein was transferred to polyvinylidene fluoride (PVDF) membrane (Millipore Corp, Bedford, MA, USA) employing transfer cell machine (Hofer, Holliston, MA, USA) and incubated for $1 \mathrm{~h}$ in blocking buffer (5\% skim milk) at ordinary temperature. Primary antibody's, iNOS (1:1000 in 5\% skim milk; \#sc-7271; Santa Cruz Biotechnology, Dallas, TX, USA), COX-2 (1:500 in 5\% skim milk; \#33345; Signalway antibody, Maryland, College Park, USA), and glyceraldehyde 3-phosphate dehydrogenase (GAPDH) (1:1000 in 5\% skim milk; \#MA5-15738; Thermo Fisher Scientific.), at $4{ }^{\circ} \mathrm{C}$. Secondary antibody's, mouse anti-rabbit lgG-HRP (1:1000; sc-2357; Santa Cruz Biotechnology.), and goat anti-mouse IgG (1:1000; 31430; Thermo Fisher Scientific.); washed 3 times, then reacted with enhanced chemiluminescence (ECL) kit (Millipore Corp.) in a darkroom and, finally, subjected to X-ray film. Each protein band was definite employing Azure Biosystems (C300, Azure Biosystems inc., Dublin, CA, USA) [7, 14, 25].

\section{Cytokine assay}

Cells were cultured in 6-well plates at a density of $1 \times 10^{5}$ cells $/ \mathrm{mL}$ by incubation for over $12 \mathrm{~h}$, at $37^{\circ} \mathrm{C}$. Then, LPS $(1 \mu \mathrm{g} / \mathrm{mL})$ was used to stimulate cells in all wells except for the normal group. Then $6.25-50 \mu \mathrm{g} / \mathrm{mL}$ of saucerneol $\mathrm{D}$ was added and the cells incubated for $18 \mathrm{~h}$. Gathered medium was saved at $-80{ }^{\circ} \mathrm{C}$ before analysis. Enzyme immune-assay (EIA) kit was utilized for determining the content of prostaglandin $\mathrm{E}_{2}\left(\mathrm{PGE}_{2}\right), \mathrm{IL}-1 \beta, \mathrm{TNF}-\alpha$, IL-6, etc. The concentrations of cytokines were definite employing a normal curve received from the reaction of standard materials [14-16, 26].

\section{Statistical analysis}

All tests were performed in triplicate $(\mathrm{n}=3)$. Statistical analysis was carried out employing one-way ANOVA in IBM SPSS Statistics 25 (Statistical Package for Social Science, Chicago, IL, USA). Duncan's multiple range tests were performed to analyze distinctions. A $P$-value of less than ${ }^{*} P<0.05$, ${ }^{* *} P<0.01$ was deemed to indicate a significant difference.

\section{Results and discussion}

Effect of elicitor on TPC and saucerneol D content and inflammatory activities on $\mathrm{S}$. chinensis

As shown in Table 1, the TPC and saucerneol D contents was compared between the elicitor non-treated group and elicitor treated groups $(1.5$, and $3 \mathrm{mg} / \mathrm{mL}$ ). As a result of measuring TPC and saucerneol D content in each group, both were higher in the elicitortreated group than in the elicitor non-treated group [27].
Table 1 TPC, saucerneol D content, HAase inhibition, and expression levels of pro-inflammatory factors in $S$. chinensis extract treated by elicitor

\begin{tabular}{lrcc}
\hline Experiment & Control & Group A & \multicolumn{1}{c}{ Group B } \\
\hline TPC $(\mathrm{mg} / \mathrm{g})$ & $7.6 \pm 0.7$ & $10.3 \pm 0.3$ & $11.4 \pm 0.5$ \\
Saucerneol D content $(\mu \mathrm{g} / \mathrm{g})$ & $248.8 \pm 5.4$ & $377.0 \pm 11.6$ & $449.9 \pm 17.4$ \\
HAase inhibition (\%) & $89.6 \pm 1.2$ & $93.9 \pm 2.9$ & $95.9 \pm 0.8$ \\
NO production (\%) & $86.8 \pm 1.8$ & $75.3 \pm 1.9$ & $68.1 \pm 3.1$ \\
iNOS expression (\%) & $70.3 \pm 0.9$ & $35.6 \pm 2.1$ & $39.1 \pm 1.4$ \\
COX-2 expression (\%) & $90.2 \pm 5.1$ & $56.1 \pm 3.2$ & $53.3 \pm 2.7$ \\
\hline
\end{tabular}

Control: no elicitor treatment, group A: $4.5 \mathrm{mg} / \mathrm{mL}$ of treatment, group B: $9.0 \mathrm{mg} / \mathrm{mL}$. Raw 264.7 cell were treated with $25 \mu \mathrm{g} / \mathrm{mL}$ of extracts from $S$. chinensis (dissolved in DW) for $1 \mathrm{~h}$ prior to addition of LPS $(1 \mu \mathrm{g} / \mathrm{mL})$. The cells were further incubated with LPS for $24 \mathrm{~h}$. Control cells were incubated with vehicle alone. The concentrations of nitrite and nitrate in the culture medium were monitored as described in the experimental procedures. Values are presented as the mean \pm error $(n=6)$

According to the above results, it can be confirmed that the useful component, which is a secondary metabolite of the plant, is increased due to the stress generated when the elite agent is treated [28]. In addition, we examined how increased saucerneol D affects hyaluronidase and pro-inflammatory-related factors, one of the enzymes involved in inflammation.

\section{Effect of elicitor on HAase activity and inflammation response (NO, iNOS, and COX-2 expression) from $S$. chinensis}

In general, it is a factor that plays an important role, such as removing bacteria and tumors by generating $\mathrm{NO}$ in vivo, but may be accompanied by genetic mutation, neurological damage, and inflammation when excessively caused by pathological processes such as disease [29, 30]. $\mathrm{NO}, \mathrm{PGE}_{2}$, cytokines, and chemokines, which are inflammatory factors induced and produced by LPS stimulation, are produced by iNOS and COX-2, proteins present in the cell nucleus. The anti-inflammatory effect is that Raw 264.7 cells are stimulated by LPS, reducing the level decrease of proteins such as iNOS and COX-2 that occur in the nucleus of the cell. In addition, anti-inflammatory effects can be expected by reducing TNF- $\alpha$ and IL-6, which are inflammatory cytokines caused by COX-2 protein [31].

As shown in Table 1, the HAase activity, and NO, iNOS and COX-2 production were compared between the elicitor non-treated group and elicitor treated groups (1.5, and $3 \mathrm{mg} / \mathrm{mL}$ ). As a result of checking whether the elicitor treated groups extract is involved in NO, iNOS, and COX-2 expression, pro-inflammatory factor was adjusted according to the concentration of elicitor treated compared to the non-treated group. These results confirmed that the useful substances amplified during the growth 
of S. chinensis through elicitor treatment inhibited proinflammatory factors. Therefore, referring to the report that saucerneol D contained in S. chinensis inhibits gastritis [27], we investigated how saucerneol D, which is expected as an active compound, affects Raw 264.7 cells.

\section{Cell viability by saucerneol $D$ from elicitor-treated $S$. chinensis}

To evaluate the cytotoxicity of saucerneol D and ammonium pyrrolidinedithiocarbamate (APDTC), saucerneol $\mathrm{D}$ and APDTC was prepared at various concentrations $(6.25-50 \mu \mathrm{g} / \mathrm{mL})$ and treated in Raw 264.7 cells. As a result, saucerneol D and APDTC was determined that there was damage to the cells as it was expressed as $76,83 \%$ at a concentration of $50 \mu \mathrm{g} / \mathrm{mL}$, respectively (Fig. 1a). Therefore, in the subsequent experiment, the concentration was adjusted and the measurement was carried out.

\section{Protein expression level of iNOS, COX-2 in LPS-induced Raw 264.7 cells}

There are two types of NOS, constitutive NOS and iNOS. Especially iNOS, induced from stimulation, produces excess amounts of NO for a long duration and the NO produced activates guanyl cyclase, which causes cell toxicity. Consequently, a reduce in iNOS protein activity in cell exposed to LPS was expected when saucerneol D was given simultaneously to the cells, creating an inflammation inhibitory effect. When the COX-2 enzyme protein is activated and expressed, it increases inflammatory cytokines and chemokines
(MCP-1, TNF- $\alpha$, TGF- $\beta$ and IL-6). Therefore, the antiinflammatory effect can be predicted by processing the sample to inhibit the COX-2 protein $[32,33]$. The COX-2 protein expression of in monocytes is enhanced by the pro-inflammatory cytokines (IL-1 $\beta$, IL-6, and TNF- $\alpha$ ). Also induce expression inhibition by glucocorticoid, IL-18 and IL-33. Consequently, selective inhibitors of COX-2 are target molecules for developing into treatments of inflammation.

The iNOS enzyme functions in way to defend from contagiousness pathogens, including viruses, and is involved in impaired immune function, circulatory disorders, various inflammatory diseases, and cancers. By confirming the inhibition of NO production by saucerneol D, the effect of saucerneol D on the expression of iNOS, a protein involved in NO production, was confirmed at the protein level through western blot. Figure as in $2 \mathrm{a}$, at the concentration of saucerneol D $25 \mu \mathrm{g} / \mathrm{mL}$, the same results were shown as the tendency to inhibit NO. The iNOS protein was expressed at $67 \%$, confirming 33\% inhibition compared to the control treated with only LPS. COX-2, a protein involved in $\mathrm{PGE}_{2}$ and cytokine activation, was also regulated by saucerneol $\mathrm{D}$ (Fig. 2b). COX-2 protein showed 56\% inhibition compared to the control treated with only LPS. Consequently, saucerneol D significantly regulated NO, iNOS involved in $\mathrm{NO}$ production, and COX-2, an important inflammatory factor involved in cytokine activation. Therefore, it was decided to examine the tendency of saucerneol D to cytokine, an important factor involved in inflammation induction.
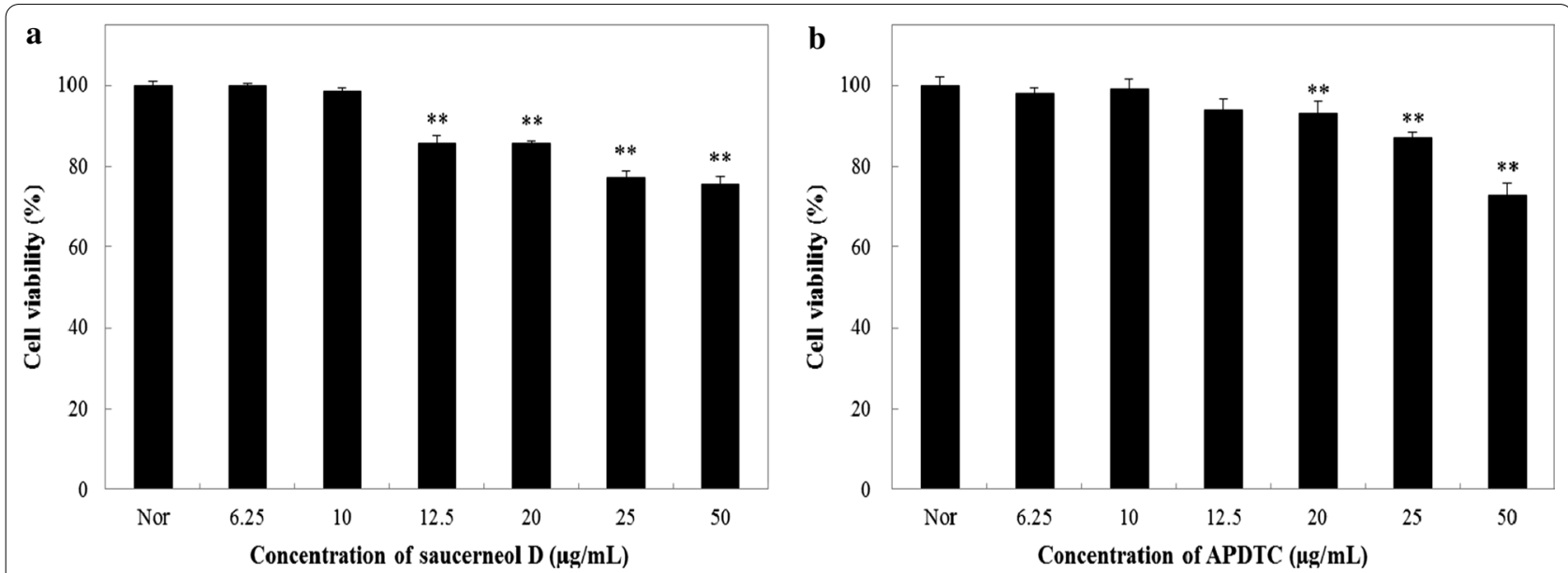

Fig. 1 MTT assay of purified saucerneol D (a) from S. chinensis and APDTC (b) in Raw 264.7 cell. Raw 264.7 cell $\left(5 \times 10^{4}\right.$ cells $\left./ \mathrm{mL}\right)$ were incubated with various concentrations of saucerneol D $(6.25-50 \mu \mathrm{g} / \mathrm{mL})$ for $24 \mathrm{~h}$. Normal group (Nor) were received in the absence of LPS. Data represent mean \pm S.D of three independent experiments $(n=3)$. The values are mean \pm SD of three independent experiments. ${ }^{* *} P<0.01$ compared with the positive control group 
a

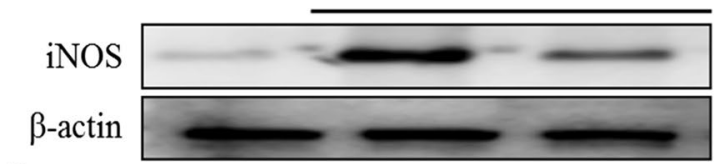

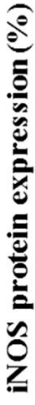$$
\begin{aligned}
& 100 \\
& 80 \\
& 60 \\
& 40 \\
& 20
\end{aligned}
$$

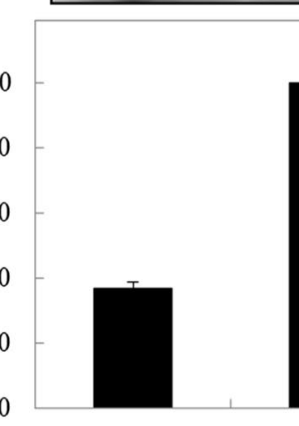

nor

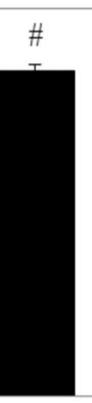

con

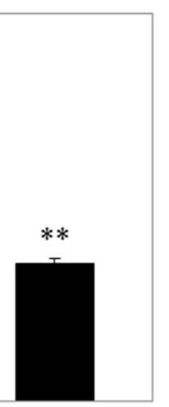

25

Concentration $(\mu \mathrm{g} / \mathrm{mL})$

b

LPS $(1 \mu \mathrm{g} / \mathrm{mL})$

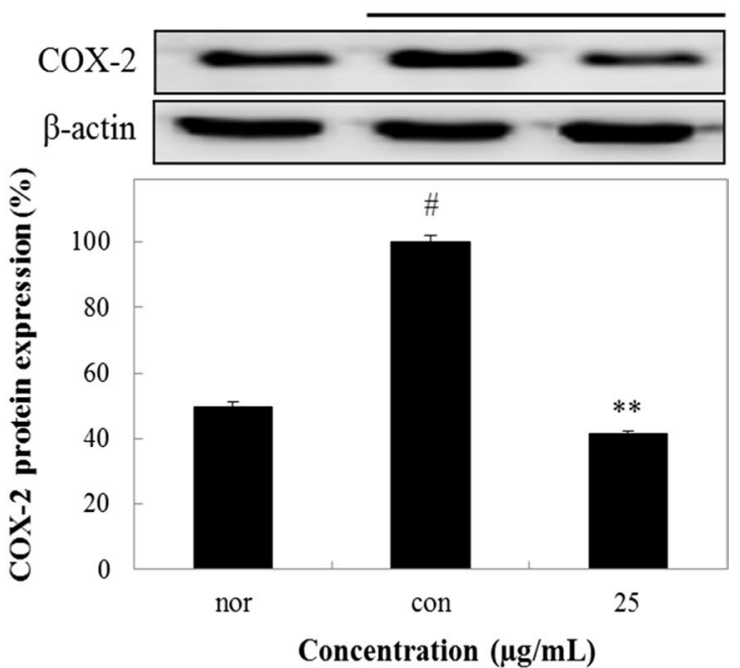

Fig. 2 Effect of purified saucerneol D from S. chinensis the expression of iNOS (a) and COX-2 (b) in Raw 264.7 cell stimulated with LPS. Raw 264.7 cell $\left(5 \times 10^{5}\right.$ cells $\left./ \mathrm{mL}\right)$ were treated with LPS $(1 \mu \mathrm{g} / \mathrm{mL})$, and, after $1 \mathrm{~h}, 25 \mu \mathrm{g} / \mathrm{mL}$ of purified saucerneol D dissolved in D.W was added. The cells were further incubated for $18 \mathrm{~h}$. Negative control group (Con) treated only LPS. The values are mean \pm SD of three independent experiments. ${ }^{\#} P<0.05$ compared with the negative control group (Con), ${ }^{* *} P<0.01$ compared with the positive control group
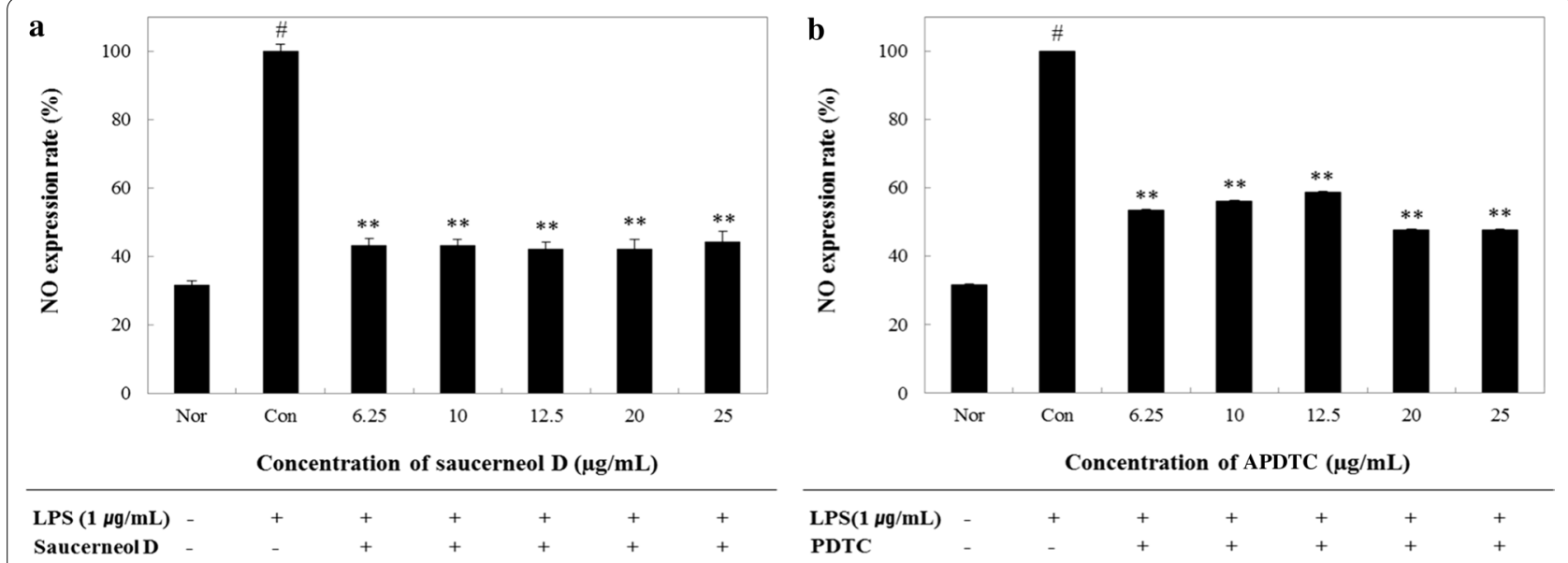

\section{LPS $(1 \mu \mathrm{g} / \mathrm{mL})$}

Saucerneol D - $\quad+\quad+\quad+\quad+\quad+$

PDTC

Fig. 3 Effect of purified saucerneol D from S chinensis (a) and APDTC (b) on NO expression in Raw 264.7 cell stimulated with LPS. Raw 264.7 cell $\left(1 \times 10^{5}\right.$ cells $\left./ \mathrm{mL}\right)$ were treated with LPS $(1 \mu \mathrm{g} / \mathrm{mL})$, and, after $1 \mathrm{~h}, 6.25$ to $25 \mathrm{\mu g} / \mathrm{mL}$ concentrations of purified saucerneol D or APDTC, as positive control, were added and the cells were further incubated for $18 \mathrm{~h}$. Normal group (Nor) were obtained in the absence of LPS. Negative control group (Con) treated only LPS. The values are mean \pm SD of three independent experiments. ${ }^{*} P<0.05$ compared with the negative control group (Con), ${ }^{*} P<0.01$ compared with the positive control group

(See figure on next page.)

Fig. 4 Expression rate of purified saucerneol D from S. chinensis and APDTC on PGE 2 (a and $\mathbf{b})$, IL-1 $\beta$ (c and $\mathbf{d})$, TNF-a (e and $\mathbf{f})$, IL-6 (g and $\mathbf{h})$ in Raw 264.7 cell stimulated with LPS. Raw 264.7 cell $\left(1 \times 10^{5}\right.$ cells $\left./ \mathrm{mL}\right)$ were treated with LPS $(1 \mu \mathrm{g} / \mathrm{mL})$, and, after $1 \mathrm{~h}, 6.25$ to $25 \mu \mathrm{g} / \mathrm{mL}$ concentrations of purified saucerneol D or APDTC, as positive control, were added and the cells were further incubated for $18 \mathrm{~h}$. Negative control group (Con) treated only LPS. The values are mean \pm SD of three independent experiments. ${ }^{*} P<0.05$ compared with the negative control group (Con), ${ }^{*} P<0.05$, ${ }^{*} P<0.01$ compared with the positive control group 

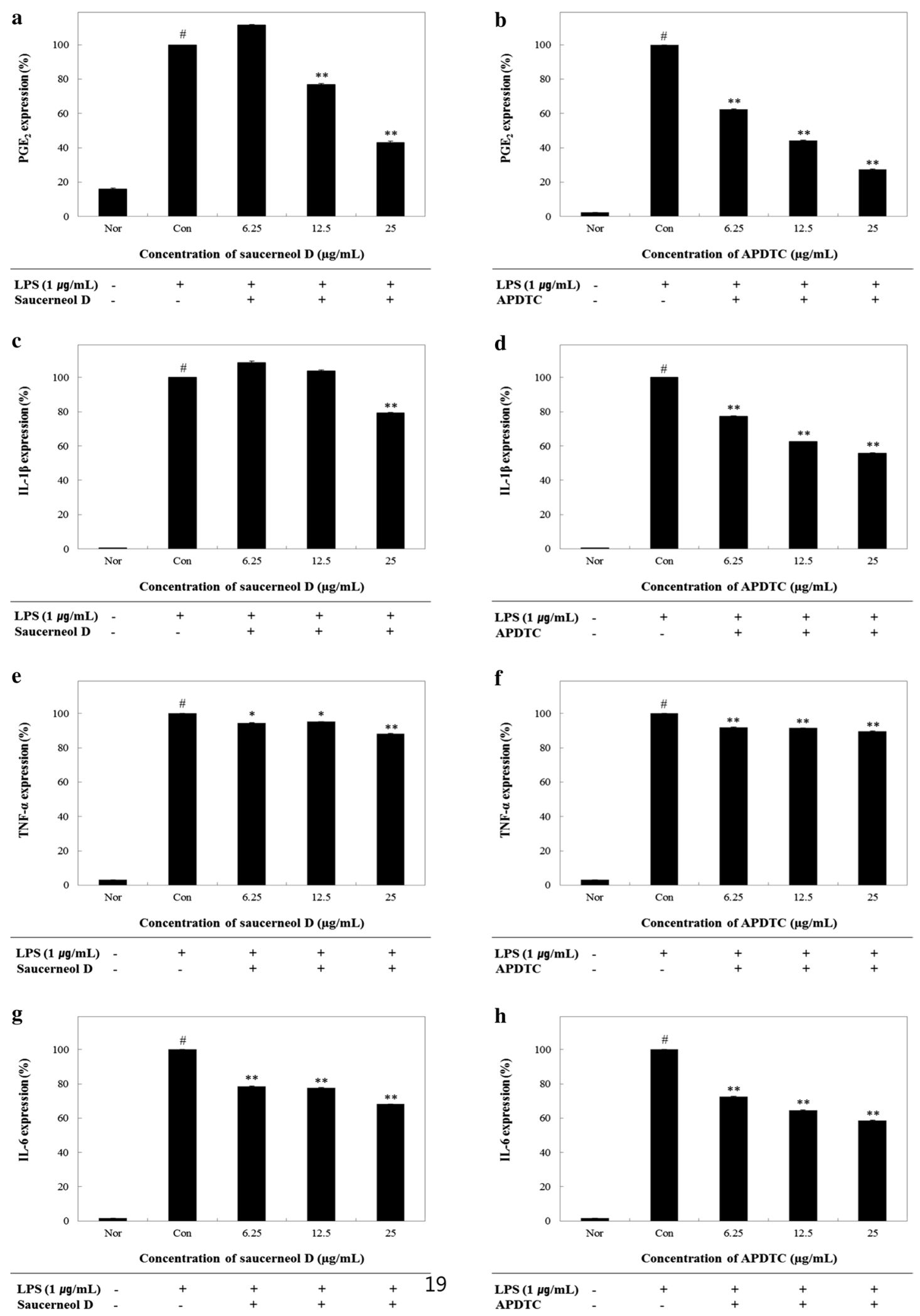


\section{Effect of NO production by saucerneol D} from elicitor-treated $S$. chinensis

PG, cytokine, NO, histamine, chemokine, bradykinin, adhesion molecule, and complement are known as mediators of inflammation. Among them, NO is a key mediator for several inflammatory reactions. $\mathrm{NO}$ is also very unstable because it is a free radical. NO is a free radical and a gaseous signaling molecule. However, excessive production of NO in the body's inflammatory response can damage cells or tissues or induce DNA mutations. NO is thus used as the most basic and important biological biomarker in identifying inflammatory responses [34, 35]. An excess of inflammatory factors causes the formation of $\mathrm{NO}, \mathrm{PGE}_{2}$, and cytokines by iNOS and COX-2 in the process of inflammation in the body. Normally, NO formation is significant important for destroying tumor cells and bacteria, but excess NO formation can cause inflammation, include nausea, dyspnea, impaired immune function, or neural damage [34-37].

By confirming that saucerneol D inhibits the iNOS protein, we examined whether the $\mathrm{NO}$ produced by iNOS was significantly reduced. To confirm NO production, cells were stimulated with LPS and then treated with saucerneol D adjusted to a concentration of $6.25-25 \mu \mathrm{g} / \mathrm{mL}$. As a result, as in Fig. 3a, the NO expression level was $44 \%$ at the concentration treated with saucerneol D $25 \mu \mathrm{g} / \mathrm{mL}$. Therefore, it showed $66 \%$ inhibition of NO production compared to the control treated with only LPS. NO production was suppressed even at the lowest concentration of $6.25 \mu \mathrm{g} / \mathrm{mL}$. Compared to APDTC, which is a positive control, saucerneol D showed greater inhibition effect. Therefore, it was examined how it affects the cytokine by inhibiting both NO inhibition, which plays an important role in cell signaling, and iNOS protein, which plays a catalytic role in $\mathrm{NO}$ production.

\section{Determination of pro-inflammatory-related cytokine expression level with saucerneol D}

To determine how saucerneol $\mathrm{D}$ affects the expression of pro-inflammatory cytokines, macrophages were treated with LPS and then saucerneol D. The results are as shown in Fig. 4. As shown in Fig. 4a, c, e, and g, $\mathrm{PGE}_{2}$ and cytokines, which are factors involved in inflammation by being activated by COX-2, showed a tendency to be significantly suppressed by saucerneol D treatment. These results are similar to those of the inflammatory expression factors iNOS and COX-2 proteins. In addition, it was used as an anti-inflammatory drug and showed similar inhibitory power to APDTC (Fig. $4 \mathrm{~b}, \mathrm{~d}$, f, and h) used as a positive control in the experiment. Therefore, it was expected that saucerneol D could be developed as a functional material by confirming that it is involved in the expression of pro-inflammatory-related factors [NO, iNOS, and COX-2, PGE ${ }_{2}$, cytokines (IL-1 $\beta$, TNF- $\alpha$, IL-6)] that are involved in inflammation.

\section{Abbreviations}

NO: Nitric oxide; iNOS: Inducible NO synthase; COX-2: Cyclooxygenase-2; MTT: 3-(4,5-dimethylthiazol-2-yl)-2,5-diphenyltetrazolium bromide; $\mathrm{PGE}_{2}$ : Prostaglandin $\mathrm{E}_{2} ; \mathrm{LL}-1 \beta$ : Interleukin-1 $\beta$; TNF-a: Tumor necrosis factor-a; TPC: Total phenolics content; LPS: Lipopolysaccharide; HAase: Hyaluronidase; APDTC: Ammonium pyrrolidinedithiocarbamate.

\section{Acknowledgements}

This research was supported by the Kyungpook National University Bokhyeon Research Fund, 2017.

\section{Authors' contributions}

EHL analyzed the data and wrote the paper. EHL edited the manuscript. YJC supervised the work. YJC revised and edited the manuscript and supervised the work. Both authors read and approved the final manuscript.

\section{Funding}

Not applicable.

\section{Availability of data and materials}

All data analysed during this study are included in this published article.

\section{Competing interests}

The authors declare that they have no competing interests.

Received: 13 May 2020 Accepted: 24 December 2020

Published online: 13 February 2021

References

1. Kim BH, Song WS (2000) The dyeability and antimicrobial activity of Saururus chinensis(I). J Korean Home Econ Assoc 38:1-9

2. Lee ST, Park JM, Lee HK, Kim MB, Cho JS, Heo JS (2000) Component comparison in different growth stages and organs of Saururus chinensis Baill. Korean J Medicinal Crop Sci 8:312-318

3. Lee ST, Lee YH, Choi YJ, Lee YH, Cho JS, Heo JS (2001) Yield and bioactive component on different compost amounts and cultural methods of Saururus chinensis Baill. Korean J Medicinal Crop Sci 9:220-224

4. Lee EH, Cho YJ (2020) Elevation of anti-oxidative activity and inhibitory activities against tyrosinase, elastase, collagenase and hyaluronidase of Oplismenus undulatifolius by elicitor treatment. J Appl Biol Chem 63(3):221-227

5. Lee JM, Son ES, Oh SS, Han DS (2001) Contents of total flavonoid and biological activities of edible plants. Korean J Diet Cult 16:504-514

6. Lim DK, Choi U, Shin DH (1996) Antioxidative activity of ethanol extract from korean medicinal plants. Korean J Food Sci Technol 28:83-89

7. Cho YJ, An BJ (2008) Anti-inflammatory effect of extracts from Cheongmoknosang (Morus alba L.) in lopopolysaccharide-stimulated Raw cells. J Korean Soc Appl Biol Chem 51:44-48

8. Kim NM, Ko SR, Choi KJ, Kim WJ (1993) Effect of some factors on extraction of effectual components in cinnamon extracts. J Korean Agric Chem Soc 36:17-22

9. Ham SS, Oh DH, Hong JK, Lee JH (1997) Antimutagenic effects of juices from edible Korean wild herbs. J Food Sci Nutr 2:155-161

10. Hubner G, Wray V, Nahrstedt A (1999) Flavonol oligosaccharides from the Seeds of Aesculus Hippocastanum. Planta Med 65:636-642

11. Moon TC, Park JO, Chung KW, Son KH, Kim HP, Kang SS, Chang HW, Chung KC (1999) Anti-inflammatory activity of the flavonoid components of Lonicera japonica. Yakhak Hoeji 43:117-123

12. Gross SS, Wolin MS (1995) Nitric oxide :pathophysiological mechanisms. Annu Rev Physiol 57:737-769 
13. So MS, Lee JS, Yi SY (2004) Induction of nitric oxide and cytokines in Macrophages by Codonopsis lanceolata. Korean J Food Sci Technol 36:986-990

14. Kanno S, Shouji A, Tomizawa A, Hiura T, Osanai Y, Ujibe M, Obara Y, Nakahata N, Ishikawa M (2006) Inhibitory effect of naringin on lipopolysaccharide (LPS)-induced endotoxin shock in mice and nitric oxide production in Raw 264.7 macrophages. Life Sci 78:673-681

15. Naoko K, Satsuki K, Shinichi W (2005) IL-17 suppresses TNF-a-induced CCL27 production through induction of COX-2 in human keratinocytes. J Allergy Clin Immunol 116:1144-1150

16. Maczynska I, Millo B, Ratajczak-Stefanska V, Maleszka R, Szych Z, Kurpisz M, Giedrys-Kalemba S (2006) Proinflammatory cytokine (IL-1 $\beta, I L-6, I L-12$, IL-18 and TNF-a) levels in sera of patients with subacute cutaneous lupus erythematosus. Immunol Letters 102:79-82

17. Cha WS, Cho YJ, Choi C (1989) The production of alkaline protease by Aspergillus fumigatus and purification of enzyme. J Korean Soc Food Nutr 18:279-286

18. Lee EH, Park HJ, Kim DH, Jung HY, Kang IK, Cho YJ (2019) Elicitor-treated extracts of Saururus chinensis inhibit the expression of inducible nitric oxide synthase and cyclooxygenase-2 enzyme expression in Raw cells for suppression of inflammation. J Appl Biol Chem 62(2):149-155

19. Tolksdorf S, McCready M, McCullagh D, Schwenk E (1949) The turbidimetric assay of hyaluronidase. J Lab Clin Med 34:74-81

20. Hwang BY, Lee JH, Nam JB, Hong YS, Lee JJ (2003) Lignans from Saururus chinensis inhibiting the transcription factor NF-kB. Phytochemistry 64:765-771

21. Folin O, Denis W (1912) On phosphotungstic-phosphomolybdic compounds as color reagents. J Biol Chem 12:239-243

22. Lee $E$ (2011) Effects of Ixeris dentata extract on the production of proinflammatory cytokines in the LPS stimulated rat and Raw 264.7 cells. Korean J Plant Res 24:604-612

23. Carmichael J, DeGraff WG, Gazdar AF, Minna JD, Mitchell JB (1987) Evaluation of a tetrazolium-based semiautomated colorimetric assay: assessment of chemosensitivity testing. Cancer Res 47(4):936-942

24. Ryu JH, Ahn H, Kim JY, Kim YK (2003) Inhibitory activity of plant extracts on nitric oxide synthesis in LPS-activated macrophage. Phytother Res 17:485-489

25. Cho YJ (2011) Anti-inflammatory effect of Jatrorrhizine from Phellodendron amurense in lipopolysaccharide-stimulated Raw 264.7 cells. J Appl Biol Chem 54:114-119

26. Nam KS, Jang SA, Sohn EH, Bak JP, Sohn ES, Koo HJ, Yoon WJ, Kwon JE, Jeong YJ, Meng X, Han HS, Kang SC (2015) Comparative study of Litsea japonica Leaf and fruit extract on the anti-inflammatory effects. Korean J Plant Res 28:145-152
27. Park SY, Song $H$, Cho YJ (2018) Elicitor treatment potentiates the preventive effect of Saururus chinensis leaves on stress-induced gastritis. Appl Biol Chem 61(4):423-431

28. Cho YJ, Park SY, Kim KB (2014) Cultivation method of increased inhibitory compounds in Saururus chinensis by yeast to enzyme degradation. Patent 10-1469901, Korea

29. Kim MK, Kim DY (2015) Anti-inflammatory effect of barley leaf ethanol extract in LPS-stimulated Raw 264.7 macrophage. Kor J Food Preserv 22:735-743

30. Kim DH, Cho JH, Cho YJ (2016) Anti-inflammatory activity of extracts from ultra-fine ground Saururus chinensis leaves in lipopolysaccharidestimulated Raw 264.7 cells. J Appl Biol Chem 59:37-43

31. Lee SJ, Lee DG, Kim MY, Kong SC, Yu KH, Kim YY, Lee SH (2016) Enhancement of anti-inflammatory activity by fermentation of Sargassum siliquanstrum. J Life Sci 26:318-324

32. Kim SC, Jung YS, Lee JR, Kim YW, Byun BH, Kwon TK, Suh SI, Byun SH, Kwon YK (2004) Inhibition effect of Phellinus Igniarius water extract on TNF-a, IL-1 $\beta$, IL-6 and nitric oxide production in lipopolysaccharideactivated Raw 264.7 cells. Korean J Oriental Physiol Pathol 18:880-886

33. Surh YJ (2002) Anti-tumor promoting potential of selected spice ingredients with antioxidative and anti-inflammatory activities: a short review. Food Chem Toxicol 40:1091-1097

34. Stuehr DJ, Cho HJ, Kwon NS, Weise MF, Nathan CF (1991) Purification and characterization of the cytokine-induced macrophage nitric oxide synthase:an FAD- and FMN-containing flavoprotein. Proc Natl Acad Sci 88:7773-7777

35. Weisz A, Cicatiello L, Esumi H (1996) Regulation of the mouse inducibletype nitric oxide synthase gene promoter by interferon-gamma, bacterial lipopolysaccharide and NG-monomethyl-L-arginine. Biochem J 316:209-215

36. McCartney-Francis N, Allen JB, Mizel DE, Albina JE, Xie QW, Nathan CF, Wahl SM (1993) Suppression of arthritis by an inhibitor of nitric oxide synthase. J Exp Med 178:749-754

37. Moon TC, Kim JC, Song SE, Suh SJ, Seo CS, Kim YK, Jin MH, Yang JH, Son JK, Jahng YD, Kim CH, Chang HW (2008) Saucerneol D, a naturally occurring sesquilignan, inhibits LPS-induced iNOS expression in Raw 264.7 cells by blocking NF-kB and MAPK activation. Int Immunopharmacol 8:1395-1400

\section{Publisher's Note}

Springer Nature remains neutral with regard to jurisdictional claims in published maps and institutional affiliations.

\section{Submit your manuscript to a SpringerOpen ${ }^{\odot}$ journal and benefit from:}

- Convenient online submission

- Rigorous peer review

- Open access: articles freely available online

- High visibility within the field

- Retaining the copyright to your article

Submit your next manuscript at $\boldsymbol{\nabla}$ springeropen.com 